\title{
Catching sea cucumber fever in coastal communities: Conceptualizing the impacts of shocks versus trends on social-ecological
}

systems

Maery Kaplan-Hallam ${ }^{a}$, Nathan J. Bennett ${ }^{a, b, c}$, Terre Satterfield $^{a}$

a Institute for Resources, Environment and Sustainability, University of British Columbia, Canada

${ }^{b}$ School of Marine and Environmental Affairs, University of Washington, USA

${ }^{c}$ Center for Ocean Solutions, Stanford University, USA

This is the accepted manuscript of a paper originally published in Global Environmental Change. You may find the final, formatted version at 10.1016/j.gloenvcha.2017.05.003.

\section{Abstract}

Research on vulnerability and adaptation in social-ecological systems (SES) has largely centered on climate change and associated biophysical stressors. Key implications of this are twofold. First, there has been limited engagement with the impacts of social drivers of change on communities and linked SES. Second, the focus on climate effects often assumes slower drivers of change and fails to differentiate the implications of change occurring at different timescales. This has resulted in a body of SES scholarship that is under-theorized in terms of how communities experience and respond to fast versus slow change. Yet, social and economic processes at global scales increasingly emerge as 'shocks' for local systems, driving rapid and often surprising forms of change distinct from and yet interacting with the impacts of slow, ongoing 'trends'. This research seeks to understand the nature and impacts of social shocks as opposed to or in concert with trends through the lens of a qualitative case study of a coastal community in Mexico, where demand from international seafood markets has spurred rapid development of a sea cucumber fishery. Specifically, we examined what different socialecological changes are being experienced by the community, how the impacts of the sea cucumber fishery are distinct from and interacting with slower ongoing trends and how these processes are affecting system vulnerability, adaptations and adaptive capacity. We begin by proposing a novel framework for conceptualizing impacts on social systems, as comprised of structures, functions, and feedbacks. Our results illustrate how the rapid-onset of this fishery has ecological changes are being experienced by the community, how the impacts of the sea cucumber fishery are distinct from and interacting with slower ongoing trends and in poaching and armed violence have emerged, exacerbating pressures from ongoing trends in immigration, overfishing and tourism development. We argue that there is a need to better understand and differentiate the social and ecological implications of shocks, which present novel challenges for 
the vulnerability and adaptive capacity of communities and the sustainability of marine ecosystems.

\section{Introduction}

The impacts of contemporary social and environmental change are particularly glaring for coastal communities, exposed to and engaged in the dynamics of both marine and terrestrial systems (Bunce et al., 2010; Ommer, 2007; Bennett et al., 2015). Coastal zones face some of the greatest biophysical impacts of climate change, including myriad consequences of rising sea levels (e.g., coastal erosion and sea water inundation) and increased variability of storms, drought, and other extreme weather events (Bunce et al., 2010). A combination of stressors such as ocean acidification and unsustainable global fishing practices has meant that coastal communities increasingly confront challenges related to gradually declining marine ecosystems, from decreased livelihood sustainability to food insecurity (Pauly and Maclean, 2003; Bennett et al., 2016). For many smaller and more remote coastal communities, declines in coastal and marine livelihoods are resulting in aging populations, as younger generations leave to pursue employment and education opportunities in urban centers (Ommer, 2007). Conversely, more populated coastal zones are often sites of demographic, economic, and land-use change, driven by processes such as tourism development and urbanization (Bunce et al., 2010). As a result of such processes, understanding the consequences of multi-scale, interacting social and environmental change presents an enduring challenge for researchers and decision makers engaged in researching vulnerability and adaptation in coastal communities (Bunce et al., 2010). While SES scholarship in this area has tended to focus on climate change (e.g., Cinner et al., 2015; Bunce et al., 2010; Julca and Paddison, 2010; Prno et al., 2011; Bardsley and Wiseman, 2013; Wise et al., 2014; O'Brien and Wolf, 2010) less attention has been given to understanding non-climatic anthropogenic drivers of change, such as broad demographic, socio-political, economic, cultural, or technological processes of change and their cross-scale impacts (Breslow, 2015; Bennett et al., 2016). In addition, there has been little differentiation between the drivers and impacts of fast versus slower forms of change among SES scholars. This is less the case in other non-SES fields, such as the psychology and sociology of risk and natural disasters (e.g., Bromet et al., 2011; Freudenburg et al., 2008) and coastal management (e.g., Mee, 2012). Given the importance of temporal characteristics (rate of onset, duration, and frequency) in research on hazards and risk (Tobin and Montz, 1997), for instance, the lack of distinction between fast and slow drivers in scholarship on community vulnerability is striking. Indeed, social drivers of rapid change play an increasing role in the opportunities and challenges being experienced by communities (Hicks et al., 2016; Breslow, 2015), with distinct consequences for their ability to respond or adapt.

Expansion of the global sea cucumber trade, triggered largely by growing demand in Asian luxury seafood markets, exemplifies such a rapid social driver of change. Sea cucumbers are slow-moving, tubular-shaped invertebrates that inhabit ocean floors worldwide (Eriksson et al., 2015). Over the past few decades, the increasing international value of sea cucumber products has sparked fishery booms, often in communities where commercial sea cucumber harvesting had not previously occurred (Eriksson et al., 2015). Moreover, Anderson et al. (2010) have shown that despite a trend of increasing global sea cucumber catches, the catch of individual 
fisheries has followed a boom-and-bust pattern, "declining nearly as quickly as they expanded" (p.1). While 'boom-bust' marine resource industries have occurred throughout history, the current speed with which markets for species of this and other echinoderms are emerging is unprecedented, supported in part by the accelerated mobility of information, technology, labour, and capital (Adger et al., 2009; Berkes et al., 2006; Eriksson et al., 2015).

While there is a growing body of research on sea cucumber fisheries, there is a dearth of studies that give specific consideration to the social dimensions of these fisheries. The limited research in this area reveals themes of social impacts and conflict reflective of terrestrial resource booms (Bremner and Perez, 2002; Christensen, 2011) and limited capacity for management resulting in overexploitation of stocks (Anderson et al., 2010; Eriksson et al., 2015). Rapid-onset sea cucumber fisheries thus represent an important but understudied driver of fast change in coastal communities, with heretofore-limited research into the associated social impacts and feedbacks and how these changes combine with ongoing social-ecological change.

To better understand the social implications of fast and slow drivers of change for socialecological systems, the research presented here investigates how a rapidly developed sea cucumber fishery has driven change in a local community through a qualitative case study of Río Lagartos, a fishing community on Mexico's Yucatán Peninsula. Specifically, we examined: a) what different social-ecological changes are being experienced by the community, b) how the impacts of the sea cucumber fishery are distinct from and interacting with slower ongoing trends and c) how these processes are affecting system vulnerability, adaptations and adaptive capacity. Below, we situate this research within the literature on social-ecological resilience, vulnerability, and adaptation in the face of multiple stressors. In so doing, we clarify the need to differentiate between the impacts of slow trends and rapid shocks and propose a framework for conceptualizing impacts to social systems in SES research.

\section{Understanding impacts and responses to change in SES}

The concept of a social-ecological system (SES) reflects an understanding that the human and biophysical components of a given landscape are inextricably linked, continuously influencing and responding to each other in a complex adaptive system (Adger, 2006; Berkes et al., 2006; Renaud et al., 2010). 'Resilience', 'vulnerability' and 'adaptive capacity' make up three of the dominant theoretical lenses through which research has examined how these linked systems experience and respond to change (Gallopín, 2006). While specific definitions of these terms vary across scholarly traditions, a broadly accepted characterization of a resilient SES is "one with the capacity to absorb disturbance and reorganize while undergoing change so as to still retain essentially the same function, structure, identity, and feed- backs" (Walker et al., 2006). Alternatively, vulnerability has been described as the "degree to which a system is susceptible to and is unable to cope with adverse effects" which is itself a function of "the stress to which a system is exposed, its sensitivity, and its adaptive capacity" (Adger, 2006 p.269). Through this theoretical lens, adaptive capacity represents the latent characteristics or attributes of a given system that enable it to respond adaptively in the face of stress, threats or perturbations (Engle, 2011; Smit and Wandel, 2006; Birk, 2014). Adaptive capacity is 'realized' through 
adaptive response (adaptation), as a system reacts to change or stress either by preparing in advance or else by adjusting, compensating and responding to effects as they unfold (Engle, 2011; Adger, 2006; Bennett et al., 2016).

An area of growing interest in particular is how multiple drivers of social-ecological change interact at varying spatial and temporal scales to influence the vulnerability of individuals, communities, and ecosystems at the local level (Bunce et al., 2010; Bennett et al., 2016; Leichenko and O'Brien, 2008). This scholarship on community vulnerability to "multiple stressors" or "multiple exposures" has centered on climate change, for example, trying to understand how climate stress interacts with economic globalization (O'Brien et al., 2004), disease epidemiology (Reid and Vogel, 2006), livelihood risks (Belliveua et al., 2006) or resource management policies (Bunce et al., 2010).

Preoccupied with global climate and environmental change (e.g., O'Brien et al., 2004; Reid and Vogel, 2006; Birk, 2014; Bunce et al., 2010; Tschakert, 2007; McCubbin et al., 2015), SES scholarship has paid less attention to social drivers of change. Notable exceptions include recent work by Breslow (2015) and Hicks et al. (2016), who demonstrate how social drivers play an ever-greater role in shaping social vulnerability in fishing communities and can be linked to local ecological changes, which push marine ecosystems towards regime shifts.

SES scholarship also often assumes slow variables, seldom differentiating between faster and slower drivers or impacts. Despite frequent reference to the varying temporal scales at which drivers exert pressure on local systems (Bennett et al., 2016; Adger et al., 2012; Bunce et al., 2010), there has been little empirical research demonstrating how the timescales of different interacting stressors relate to community vulnerability. The role of temporal variation has often been masked by a dependence on different terms, each used to characterize or represent sources of SES change. Consider, for example, stressors (O'Brien et al., 2004; Bunce et al., 2010), exposures (O'Brien and Leichenko, 2000), shocks (Schwarz et al., 2011), trends (Bennett et al., 2016), and perturbations (Gallopín, 2006). However, while some of these terms (e.g., shocks or trends) imply differing timescales or magnitudes of pressure, the terms are often used interchangeably and applied to both slower and faster forms of change. Yet, as globalization and technology produce growing interconnectedness between SES across geographic scales, our ability to differentiate the nature, scale, speed, and implications of change is key (Berkes et al., 2006). This is particularly true for fast change as social processes at global scales increasingly emerge as 'shocks' for local systems, driving rapid and often surprising forms of change, distinct from and yet interacting with the impacts of slower drivers (Armitage and Johnson, 2006).

Furthermore, while social and ecological systems are interdependent, they also have inherent differences that carry implications for how we conceive of vulnerability, resilience, and adaptation (Davidson, 2010; Armitage et al., 2012; Cote and Nightingale, 2012). Agency, values, power dynamics in different social systems, and the role of human cognition and decisionmaking differentiate social systems from ecosystems - adding layers of complexity to the ways in which humans experience, anticipate, and respond to change (Armitage et al., 2012; 
Davidson, 2010; Cote and Nightingale, 2012). However, the natural science heritage from which resilience and vulnerability thinking has emerged has meant that the ecological dimensions of these systems have received far more theoretical attention than social ones (Armitage et al., 2012). For instance, conceptions of ecosystem structure, functioning, and feedbacks are well developed while their social counter-parts have not benefited from the same level of attention. Much of the SES scholarship thus utilizes the above terms without elucidating how they may differ for social versus ecological dimensions of these linked systems.

This lack of distinction represents a conceptual hurdle within SES scholarship and can be summarized as having helped to cultivate: 1 ) insufficient engagement with the role of social drivers of change in SES vulnerability and adaptation research, 2) the under-theorization of faster verses slower drivers of change, resulting in limited understanding of the impacts of rapid change on communities and related ecosystems, and 3) less conceptual attention to the social dimensions of SES in general. We seek to address these shortcomings in the SES literature. Below, we review the literature on faster versus slower drivers of change and then propose a framework for conceptualizing change in social systems.

\subsection{Differentiating fast and slow change}

Timescales play an important role in the way that communities experience and respond to social-ecological change (Lindsay and Boyd 2010; Grothmann and Patt, 2005 Grothmann and Patt, 2005). Gradual changes allow greater time for the development of adaptive responses that prevent or mitigate negative impacts. Adaptive management entails multiple stages of learning, planning and responding. It takes time to gain an understanding of system changes of interest, to develop foresight around likely trajectories of change and anticipate necessary actions, and to share information across groups and through networks (Armitage et al., 2008). In contrast, fast changes can overwhelm the ability of institutions to effectively reduce harm from a stress (Berkes et al., 2006; Eriksson et al., 2015) and institutional response is virtually always deeply challenged by conditions of acute, novel or unexpected change (Berkes et al., 2006). Fast variables also provide less time for communities to adjust psychosocially (Vanclay, 2002; Lorenz, 2010). Part of human resilience throughout history has been the ability to normalize changing social and environmental contexts by integrating new variables and adapting expectations of the social-ecological system in which they are a part (Lorenz, 2010; Vanclay, 2002). However, rapid social or environmental change, such as dramatic changes in local demographics (e.g., rapid migration), markets (e.g., stock market crashes), or ecosystem health (e.g., oil spills), can be much more distressing than slower forms of change (Vanclay, 2002). Change that is perceived as 'too different, too fast' may also be felt more intensely than gradual change by conflicting with norms and expectations and thereby triggering feelings of insecurity (Vanclay, 2002).

For the purpose of the research presented in this paper, Table 1 provides definitions of fast versus slow variables, which we hereafter refer to as shocks and trends - adapted from definitions found in Turner et al. (2003) and Walker et al. (2004, 2012). We define 'trends' as external drivers of gradual (slow), ongoing change that influence the structure, function, or feedbacks in social-ecological systems. Examples of trends that might build pressure over time 
include rising ocean temperatures, soil degradation, or the opening of global commodity markets. Alternatively, 'shocks' can be defined as external drivers of rapid and dramatic change that affect elements of social-ecological systems (Turner et al., 2003). Examples include natural disasters such as hurricanes, market crashes, and military coups. Where a trend represents gradually increasing pressure, typically within the normal range of system variability, shocks can be considered as spikes in pressure that are outside of the normal range of variability (Turner et al., 2003).

Table 1. Proposed Definitions of Trends and Shocks.

\begin{tabular}{|l|l|}
\hline Trends & $\begin{array}{l}\text { External drivers of gradual, ongoing change that influence the structure, function, or } \\
\text { feedbacks of a system. }\end{array}$ \\
\hline Shocks & $\begin{array}{l}\text { External drivers of rapid, dramatic change that influence the structure, function, or feedbacks } \\
\text { of a system. }\end{array}$ \\
\hline
\end{tabular}

\subsection{Conceptualizing change in social systems}

To further the integration of social dimensions with social-ecological systems thinking and language, we offer a conceptual framework in Table 2, which elaborates our proposed description of core social system elements. In this framework we build on theories of ecological resilience (see Holling, 1973), social-ecological resilience (found in Folke, 2006; Walker et al., 2004) and thinking about resilience in social systems (found in Cote and Nightingale, 2012; Armitage, 2012; Lorenz, 2010; Davidson, 2010). Our aim is to better specify and operationalize social system structure, function, and feedbacks by providing categories and examples of these in reference to social systems as opposed to their well-established use in ecological systems. In our corresponding frame- work, social system structure is represented by system components (e.g., actors and resources) that are organized into sets of interrelations in such forms as networks, institutions, livelihoods, and social hierarchies. Social system functions include the processes and outcomes of component interactions. Specifically, social 'processes' refers to decision-making and action-taking - for example, relating to the management and allocation of resources. Social outcomes are separated into two categories. 'Relational and psychological outcomes' refers to the quality of relations between individuals and groups, as represented by levels of social cohesion versus social disintegration, and to psychological wellbeing, which emerges in such forms as fears, aspirations or sense of agency. 'Material and physical outcomes' refer to material wealth, such as levels of income, food security, or access to resources, and to physical health, such as absence of disease or infirmity. Finally, social system feedbacks are responses that influence the direction of a change in system structure or function. Building on Bennett et al. (2016), we suggest that feedbacks can be of three types: 1) stabilizing, where a response reduces or mitigates undesirable change in the system 2) amplifying, where a response exacerbates undesirable change, and 3) adapting, where a response produces desirable change in the system.

By characterizing social system structure, functions and feedbacks, this framework aims to provide terminology and concepts for investigating social dimensions in a manner congruent with SES thinking and language thus enabling interdisciplinary scholarship. It can be differentiated from existing SES frameworks, such as Ostrom (2009), in that it creates space for 
analysis of the social subsystem of a given SES beyond the institutional factors influencing the state of a resource (Cote and Nightingale, 2012). For example, by conceptualizing functional outcomes as related to dimensions of relational, psychological, material and physical wellbeing, this framework supports deeper engagement with insights from well-developed areas of social theory on the manifold ways that social-ecological change can impact communities. Further, as critical thresholds in SES are often defined as points of change in structure, functions, and feedbacks, we believe such a framework may assist in the investigation and characterization of thresholds in social and social-ecological systems. In the case study below we apply this framework to examine the social consequences of a rapidly developed sea cucumber fishery (i.e., a 'shock') as an example of how it might be applied in SES research.

Table 2. Conceptual Framework for Social System Elements

\begin{tabular}{|c|c|c|}
\hline & Definition/description & Categories with Examples \\
\hline $\begin{array}{l}\text { Social System } \\
\text { Structure }\end{array}$ & $\begin{array}{l}\text { Components of the } \\
\text { system in a set of } \\
\text { interrelations }\end{array}$ & $\begin{array}{l}\text { Components } \\
\text { - Actors } \\
\text { - Resources (e.g. fish stocks) } \\
\text { Structure of interrelations } \\
\text { - Institutions } \\
\text { - Networks } \\
\text { - Livelihoods } \\
\text { - Social hierarchies }\end{array}$ \\
\hline $\begin{array}{l}\text { Social System } \\
\text { Functions }\end{array}$ & $\begin{array}{l}\text { The processes, relations, } \\
\text { and outcomes of } \\
\text { component interactions. }\end{array}$ & $\begin{array}{l}\text { Processes } \\
\text { - Management of resources } \\
\text { - Decision making } \\
\text { - } \text { Allocation of public goods and services } \\
\text { Relational and Psychological Outcomes } \\
\text { - Social cohesion, trust, tension, conflict } \\
\text { - Equity and gender relations } \\
\text { - Sense of security, agency, empowerment, belonging } \\
\text { Material and Physical Outcomes } \\
\text { - Food security and physical health } \\
\text { - Wealth, income, and assets } \\
\text { - Cultural integrity/persistence vs. cultural } \\
\text { marginalization }\end{array}$ \\
\hline \multirow[t]{3}{*}{$\begin{array}{l}\text { Social System } \\
\text { Feedbacks }\end{array}$} & Stabilizing (Mitigative) & $\begin{array}{l}\text { Internal responses that reduce/mitigate undesirable change } \\
\text { in system structure and function }\end{array}$ \\
\hline & Amplifying (Maladaptive) & $\begin{array}{l}\text { Internal responses that drive further undesirable change in } \\
\text { system structure and function }\end{array}$ \\
\hline & Adapting (Adaptive) & $\begin{array}{l}\text { Internal responses that drive desirable change in system } \\
\text { structure and function }\end{array}$ \\
\hline
\end{tabular}

\section{Research context and methods}

\subsection{Research site}

The town of Río Lagartos (pop 2000) is located on the north-eastern end of Mexico's Yucatán Peninsula, in the State of Yucatán (Fig. 1). Río Lagartos is situated, along with the communities 
of Las Colorados, San Felipe, and El Cuyo, within the buffer zone of the Ria Lagartos Biosphere Reserve (RLBR). The biosphere reserve, designated in 1999, covers 150,000 acres of important marine, coastal and terrestrial environments, including wetlands, mangroves, estuaries, marshes, savannah, grasslands, coastal dunes, lagoons and multiple classifications of forest (UNESCO).

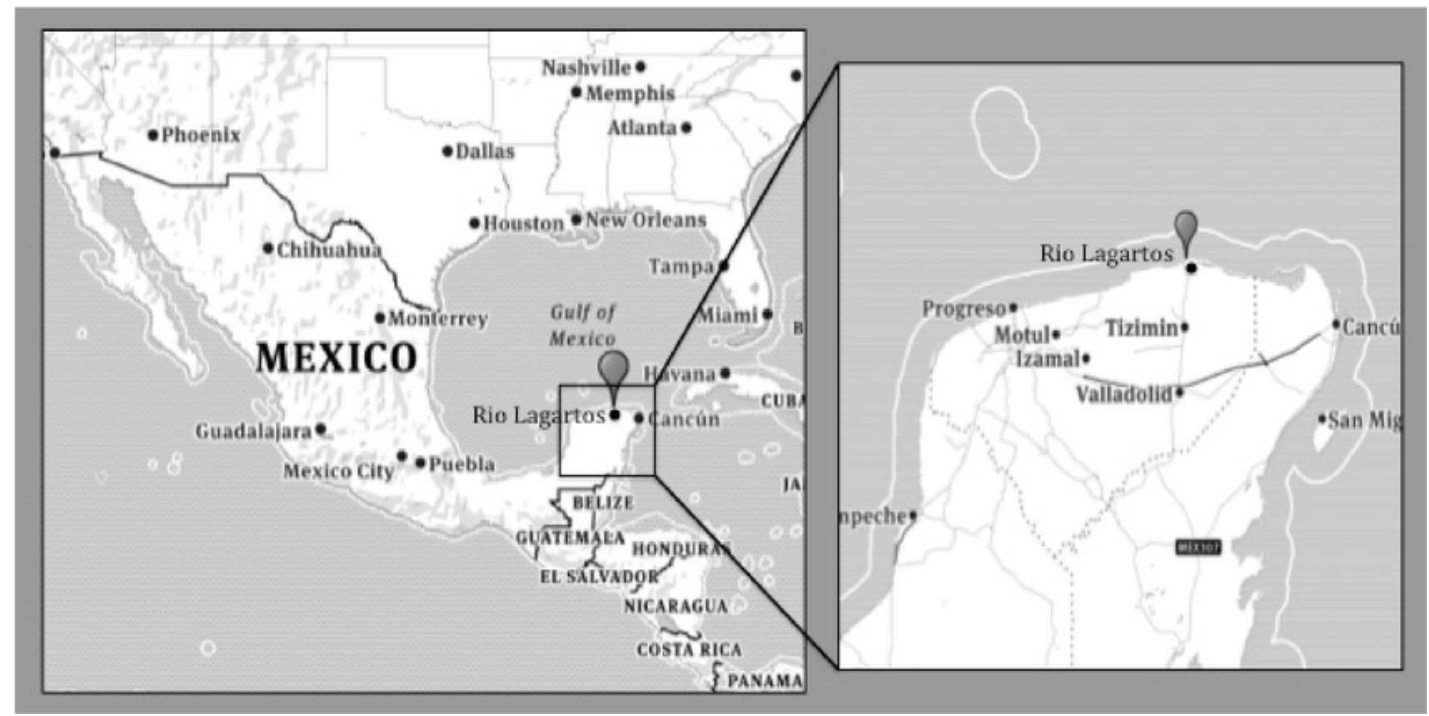

Figure 1. Location of Rio Lagartos

For the past 50 years, small-scale commercial fishing has made up the dominant livelihood of the region, with octopus, spiny lobster, red grouper, snapper, and most recently, sea cucumber as the key commercial species (Pedroza and Salas, 2011; Bennett, 2016a; Fraga, 2006). While cooperative models characterized the early decades of commercial fishing in Yucatán, deregulation and privatization of state fisheries over the 80 's and 90's, including the removal of exclusive access rights for fishing cooperatives, resulted in dramatic growth in the private sector (Pedroza and Salas, 2011). In Río Lagartos, two long-standing cooperatives account for around half of the fishers in the community, while the rest participate in patron-client relationships (Bennett, 2016a).

Foreign buyers of sea cucumber first arrived to Yucatán's two main fishing ports of Progresso \& Celestún in the early 2000's, and the National Fisheries Commission, CONAPESCA, began issuing permits for short seasonal openings for two species of sea cucumber (Isostichopus badconotus and Holuthuria floridana) in 2010 (Bennett, 2016a). With the growth of Yucatán's commercial fishing industry over the 80's and 90's, and then subsequent declines in key commercial species, the lucrative nature of sea cucumber harvesting represented a significant economic opportunity for fishers in the region (Pedoza and Salas, 2011). Indeed, the first years of sea cucumber fishing in Yucatán were characterized by huge economic profits for participating fishers.

In Río Lagartos, cooperatives and independent fishers received their first commercial sea cucumber permits in the spring of 2013. While federal regulations for sea cucumber harvesting 
include limited access permits, quotas, and closed seasons, Bennett (2016a) suggests that "the limited presence of State authorities in fishing communities has meant that local fishing institutions are the primary moderating force of market pressures", implementing their own 'de-facto' management of local fisheries. She notes that in communities such as Celestún, this process has led to what are essentially 'open-access' fishing regimes whereas in Río Lagartos, local cooperatives have taken efforts to monitor fishing activity and enforce regulations.

\subsection{Data collection and analysis}

A qualitative case study approach was chosen to allow for detailed analysis of perceived socialecological change (Merriam, 2001). Field data collection took place between July 2015 and October 2015 and involved two ethnographic techniques: semi-structured interviewing and participant observation. From August to September, the first author lived in the community to support daily engagement with community members, flexible interview scheduling, and continuous exposure to community life. 'Grey' document analysis, including governmental and non-governmental reports on the management of sea cucumber fisheries at regional (Yucatán State), national (Mexico) and international scales, as well as online news media, provided key sources of secondary data.

Interview participants were selected through convenience and purposive sampling to engage a cross section of community members 18 years of age and older (see Table 3 ). Interviews were conducted with a semi-structured protocol and ranged from 30 to $90 \mathrm{~min}$ in length. The interview began with open-ended questions about life and livelihoods in the community, and perceived changes over time. Once participants mentioned observing a particular change, prompts were used to initiate discussions of the perceived drivers, impacts (positive and negative), local responses to, and future trajectories of change. Interview transcriptions and field notes were coded and analyzed with NVivo qualitative data analysis program. Data was open-coded to categorize perceived changes, associated drivers and impacts, and local responses. Narratives of key events, change processes, and outcomes were then analyzed with more depth to build an understanding of the relationships between them, and characterized with the social systems framework presented in Section 2.2 with specific attention to the sea cucumber fishery.

Broadly, limitations of the methods used in this research are those inherent to case studies, the sampling method used, and qualitative research using perceptions. These limitations include lack of statistical representativeness of the sample (Miller and Crabtree, 2004) and the filtering of objective reality through social context and perceptions (Merriam, 2001; Bennett, 2016b). A further limitation is that the research did not engage fishers who migrated to the community to harvest sea cucumber. However, the qualitative case study approach was deemed appropriate for its ability to gather rich and nuanced data about local experiences of coupled socialecological change (Lyons et al., 2016). 
Table 3. Summary of Interview Participants.

\begin{tabular}{|l|l|l|l|l|}
\hline Livelihood Group & Description & $\begin{array}{l}\text { Males } \\
\text { Ages 22-81 }\end{array}$ & $\begin{array}{l}\text { Females } \\
\text { Ages 22-68 }\end{array}$ & Total \\
\hline Fishing & $\begin{array}{l}\text { Fishers (co-op \& independent), their wives, and } \\
\text { women gleaners }\end{array}$ & 10 & 4 & 14 \\
\hline Tourism/Hospitality & $\begin{array}{l}\text { Guides (co-operative and independent), } \\
\text { restaurant \& hotel owners and employees }\end{array}$ & 13 & 2 & 15 \\
\hline $\begin{array}{l}\text { Municipal } \\
\text { Leadership }\end{array}$ & Current \& Past Mayors & 2 & 1 & 3 \\
\hline Reserve Staff & Technical Operator \& Park Guard & 1 & 1 & 2 \\
\hline Ranching & Ranchers (working \& retired) and their wives & 3 & 1 & 4 \\
\hline Small Business & Store Owner & & 1 & 1 \\
\hline Total Participants & & 29 & 10 & 39 \\
\hline
\end{tabular}

\section{Results: a changing system}

\subsection{Gradual changes in the community}

Interview participants reported a consistent set of changing socio-economic and biophysical conditions in the community that occurred over different timelines. Participant observations about changes in the last 10-50 years were mostly linked to several slowly emerging drivers of change, such as population growth, urban development, and a growing tourism industry associated with the Ria Lagartos Biosphere Reserve (Table 4). Some conditions resulting from these drivers brought desirable outcomes for the community, such as the economic benefits and livelihood opportunities related to tourism demand and development. Other trends, such as a gradual decrease in fish catches since the late 90's, or increasing housing pressure, represented mounting challenges. Bounded in by the RLBR, the community of Río Lagartos is unable to acquire new land for housing.

Community members have responded to these changing social and environmental conditions in a variety of ways. In response to fisheries declines, fishers reported increasing fishing effort, diversifying or changing livelihoods, and seeking short-term support through social networks and local organizations. Local entrepreneurs are actively cultivating a local eco-tourism industry by leveraging the attraction of the biosphere reserve, with a growing number of fishers now giving 'eco-tours' part or full-time. Responses to housing pressure included youth moving to different towns, the illegal construction of homes within the mangroves and coping by living with extended family. The community has developed a range of responses to mitigate the economic impact of seasonal fluctuations in fishing and tourism industries, such as shrimping in the estuary and accessing loans from fishing cooperatives. 
Table 4. Summary of Reported Change Over Time.

\begin{tabular}{|l|l|}
\hline Change & Sample Quote \\
\hline $\begin{array}{l}\text { Decreasing Fish } \\
\text { Catch }\end{array}$ & $\begin{array}{l}\text { "Fishing has diminished significantly, twenty years ago there was a lot of fish but in the } \\
\text { last twenty years the truth is it has decreased a lot. If we talk about the } 80 \text { 's, the } 90 \text { 's, } \\
\text { there was a lot of fish..." }\end{array}$ \\
\hline $\begin{array}{l}\text { Fishers becoming } \\
\text { Tour Guides }\end{array}$ & $\begin{array}{l}\text { "Some (fishers) have changed from fishing to tourism... they prefer tourism because it } \\
\text { is less dangerous, and it's faster money. }\end{array}$ \\
\hline $\begin{array}{l}\text { Population } \\
\text { Increase }\end{array}$ & $\begin{array}{l}\text { "Yes, the increase in people and the growth of the port... Many people have come } \\
\text { from elsewhere." }\end{array}$ \\
\hline $\begin{array}{l}\text { Mangrove } \\
\text { composition }\end{array}$ & $\begin{array}{l}\text { "A lot has changed. Like the mangroves, before there were large and more... trees but } \\
\text { now are those that grew after the hurricane. They were taller and evenly matched } \\
\text { before." }\end{array}$ \\
\hline $\begin{array}{l}\text { Decrease in } \\
\text { Ranch Work }\end{array}$ & $\begin{array}{l}\text { "Before there was a lot of work in the ranches and now there isn't any. Now they have } \\
\text { two or three people, nothing more. In the past they hired us to cut grass in the } \\
\text { pastures but now there is no work for the day labourers. }\end{array}$ \\
\hline Housing Pressure & $\begin{array}{l}\text { "The village is growing and because of that they are fighting here, because there are } \\
\text { people born here, people from here and there is no piece of land for them to live on. } \\
\text { They live in the same house with their (extended) family and that's not right." }\end{array}$ \\
\hline $\begin{array}{l}\text { Hospitality \& } \\
\text { Tourism } \\
\text { Development }\end{array}$ & $\begin{array}{l}\text { "It (tourism) has increased, and has become widespread in Río Lagartos, it was } \\
\text { previously very low, no one spread it nor promoted in the past, but now they have } \\
\text { done more promotion." }\end{array}$ \\
\hline
\end{tabular}

\subsection{Sea cucumber fishing: a shock amongst trends}

In stark contrast to ongoing trends described above, the local sea cucumber fishery emerged as a salient driver of rapid, dramatic and predominantly undesirable change over the past 1-4 years. Changes associated with sea cucumber fishing received a significant amount of attention across the interview transcripts, with five of the six top-mentioned local change processes (i.e., decreasing fish catch, increasing numbers of non-local fishers, a developing hospitality and tourism industry, increased housing pressure, increasing community conflicts, and an increasing occurrence of illegal fishing activity) reported as either introduced or dramatically exacerbated by the start of the fishery. Below, we demonstrate how the sea cucumber fishery has driven and continues to drive changes in structure, functioning and feedbacks in the social system. These changes are summarized in Table 5. 
Table 5. Changes to Social System Associated with the Sea Cucumber Fishery.

\begin{tabular}{|l|l|}
\hline Aspect of Social System & Changes Associated with the Sea Cucumber Fishery \\
\hline Structure & $\begin{array}{l}\text { Fishing Livelihoods: New income opportunities within the sea cucumber } \\
\text { fishery; Increased competition; New risks associated with fisher-fisher conflict. } \\
\text { Actors: Introduction of migrant fishers, patrons (independent permit holders), } \\
\text { regional buyers \& poachers. } \\
\text { Resources: Declines in sea cucumber; Increased pressure on other commercial } \\
\text { and subsistence species }\end{array}$ \\
\hline Functions & $\begin{array}{l}\text { Management of Local Resources; Decreased ability of cooperatives to manage } \\
\text { harvesting pressure and prevent illegal fishing activity } \\
\text { Income: Decreased profitability of fishing } \\
\text { Fisher Health: Increase in decompression illness and death } \\
\text { Conflict, Sense of Security, and Social Cohesion: Rapid increase in 'others' with } \\
\text { different values and habits; Increase in violent conflict and 'deviant' behaviour }\end{array}$ \\
\hline Feedbacks & $\begin{array}{l}\text { Increased Fishing Effort: Increase fishing distance and hours to make up for } \\
\text { declining stocks } \\
\text { Vigilante Justice: Confront poachers at sea, attempt to dissuade or bring to } \\
\text { police } \\
\text { Protest: Set up road blockades at entrance to town to call attention of } \\
\text { regulators and government Bearing the effects: Change nothing, wait until sea } \\
\text { cucumber is extirpated or government takes action. }\end{array}$ \\
\hline
\end{tabular}

\subsubsection{Changes in social system structure}

According to interview participants, the first few years of sea cucumber fishing in Río Lagartos were characterized by dramatic changes in fishing livelihoods, actors, and resources.

The initial wave of sea cucumber harvesting brought huge profits to the livelihoods of participating fishers, with daily earnings that were double or triple incomes derived from fishing other commercially valuable species such as lobster. Local news media described the coast of Yucatán as struck with a 'gold fever' (Hugo Michel, 2013) as people rushed to benefit from local sea cucumber stocks. One woman described the substantial profit increase for some of the local fishers, saying:

Of the sea cucumber it is true that the early days had a lot of profits in the thousands of pesos. There were those who earned 30 thousand pesos ( USD1628) in a day of fishing, 3 days of 40 thousand pesos... (Housewife, Fishing Household)

In comparison, fishers harvesting spiny lobster typically earn about USD150 from a day of fishing. Yet participants would quickly reference the trade-offs that accompanied such a spike in profitability.

A few years ago the sea cucumber (fishery) started and people actually managed to make some money, they did well, there are people who bought more boats, there are people who built new homes, the patrons had more money, created, bought more boats, bought new vehicles... It brought more profit to the fishermen... But also brought with it a number of problems, it brought many problems. (Tour Guide) 
The 'problems' referenced above specify the influx of non-local actors such as fishers, buyers, patrons, and poachers to the State, a change which was directly attributed to the aforementioned spike in profitability. Interview participants frequently mentioned the increased presence of patrons (independent permit holders) in the community. Working separately from the local cooperatives, patrons contract individual fishers to land catches for them, often providing fishers with the use of boats and gear as well as loans (Bennett, 2016a). With the profitability of initial sea cucumber harvests, patrons brought increasing numbers of non-local fishers to work their boats:

Respondent (R): It's been 4 years since the people started coming. Interviewer (I): And why 4 years, do you know?

$R$ : Because we discovered another product that was here, the sea cucumber. That attracted the people. (Fisher)

What has resulted is a dramatic increase in the number of fishers and boats on the water, particularly during sea cucumber openings:

If normally there are 150 boats from one cooperative and 100 from the other, that's already 250 boats. In the sea cucumber season-400 boats come just from el Cuyo!" (Political Leadership)

The sea cucumber fishery is likewise attributed with recent incursions of poachers who illegally harvest sea cucumber. Describing the poachers, one man said:

...people from Dzilam and Celestún, still they go fishing. You do not know, you're sleeping and they are fishing at night and sometimes during the day, you do not know, they are fishing. That's never going to stop, the (foreign) people are going to fish. We respect (the closures) but they do not. (Tour Guide)

Increased harvesting pressure from the growing number of non-local fishers, including poachers, was described as having a tangible impact on marine resources both sea cucumber and other species, including grouper and crustaceans. For example, the gleaners interviewed reported that the amount of blue crab they could harvest had decreased drastically over the past two years as a result of harvesting by "fishers from away".

It's already been quite some time and the sea cucumber has not recovered. We have (sea cucumber) but little by little we are running out of it because the poachers (will) continue fishing every day until it runs out how it ended in Progresso, they stopped fishing. (Fisher)

\subsubsection{Change in social system functions}

Referencing our framework's meaning of function, respondents' concerns focused on current and future implications for local resource management as normally delivered by co-operatives, income provisioning, fisher health, and overall safety, security, and social cohesion in the community. 
The increase in patrons and non-local fishers has resulted in dramatically increased competition and a reduced ability of cooperatives to manage resources and fishing pressure. Members of cooperatives do not and did not have exclusive fishing rights, thus the changing ratio of independent versus cooperative fishers has hindered the ability of cooperatives to control harvesting through collective enforcement mechanisms used previously. Co-operative members thus described feeling overpowered by the influence of independent patrons, who are seen to have financial and political capability to get away with fishing outside of the legal openings.

They (patrons) are growing and cooperatives are down because we are affiliated under the laws and not allowed to grow. They as permit holders, as individuals, as independents, they grow when they want (saying) "I put a boat (on the water) and nobody can tell me anything. (Fisher)

According to locals, illegal sea cucumber harvesting and the challenges it brings are supported by corruption in the state government. Illegal fishers, often described as mafia or 'narcopepineros' to reflect an association with drug traffickers, and are seen as having influence over (or being in partnership with) corrupt authorities and decision makers - those also responsible for enforcement.

We have brought them (illegal fishers) before the authorities and nothing ever happens; Why doesn't anything happen? Because it is a permit holder who has a lot of influence... (Fisher)

As increasing participation in the fishery exacerbates the pressure on already overexploited stocks there was concern amongst respondents about the future of fishing as a source of income for the community. A few interviewees were optimistic that there would be a solution to the problem of overexploitation, but most suggested that the future of fishing livelihoods, particularly for younger generations, was bleak.

You no longer harvest enough (fish), sometimes you only recover enough for gasoline... Day by day the (private) businesses are increasing, this generates more fishers and less fish; and our sons are going to have to go double the distance than us to be able to fish. (Fisher)

Pursuit of previously unimaginable profits during the very short fishery opening has also had severe health consequences. Many sea cucumber fishers have been compelled, that is, to dive more often and at greater depths than is physically safe, increasing their vulnerability to health complications from decompression sickness. Fishers described harvesting sea cucumber, in comparison to other dive fisheries such as lobster, as particularly difficult and physically exhausting work.

'With the cucumber (the boat) goes, you don't return (to the surface). You don't leave (the ocean floor) because once you fill a bag of 50 kilos of cucumber you are pulled along the bottom...they throw out a buoy with another bag... and you keep working there and it's very deep where they are... now they are diving cucumber for like 20 miles and it's a really great depth.' (Fisher) 
Consequently, temporary sickness, long-term disability and death from decompression are described as increasingly common, especially for newer divers and those without adequate training or experience (fisher health).

The changes associated with the fishing industry have also brought conflict, a sense of insecurity and concern over the erosion of social cohesion within the community. The start of sea cucumber fishing triggered a wave of violent conflicts between fishers across the Yucatán coast, with some news media referring to sea cucumber fishing as the "center of conflict between Yucatecans" (Diario de Yucatán, May 12, 2013). Disputes in and around Río Lagartos have emerged such as those between local cooperative fishers and outside fishers found harvesting or attempting to harvest sea cucumber illegally - either without permit or outside of the legal openings. In Río Lagartos, tales of violent conflict, of fishers being kidnapped, murdered, and thrown into the sea are woven into discussion of the fishery itself.

There was... among the mangroves along the coast, an illegal camp for boiling and processing sea cucumber... That was last year. Then the authorities knew that and went along the coast and there was shooting between police and (illegal) fishermen from Dzilam. Shots were fired and we were there. There were even people (cooperative fishers) of San Felipe, who were grabbed and beaten, hurt, and that had never happened here, to get into a fight at sea with other people. So (sea) cucumber is a conflict that never happened (before)". (Tour Guide)

Beyond specific confrontations between poachers and locals, non-local fishers are associated with rising levels of local violence more generally, as well as 'deviant' behaviours such as drug use, prostitution, and theft. As a result, interviewees described the influx of "outsiders" as causing an increased sense of insecurity regarding physical safety and the security of property.

Before, we didn't have to worry about anything, but those people started coming, but now we're being careful a lot, especially those with young children, because we do not know what habits that have. Recently they even beheaded someone nearby, and we are not used to this because people here are very peaceful, they are not aggressive people. (Housewife, Ranching Household).

One respondent talked about the increase in theft and resulting changes in local behaviour and way of life, saying:

They started to rob motors too. Two fishers, they took their boat and motor. It's new, it came with the sea cucumber problem. It began when they started to fish sea cucumber because they had never stolen engines and boats... People already started putting cameras in front of the seawall to their boats, and hired a guard to walk on the boardwalk, to watch the boats... And the people were afraid because they are stealing boats and that had never happened here, it was quiet. (Tour Guide)

When participants were first asked about life in the community many responded by describing how friendliness and strong social relations were valued aspects of living in Río Lagartos. A 
commonly expressed sentiment was that locals did not want their community to become like the nearby fishing town of Celestún or the tourist hub of Cancun, because of the way that rapid increases in immigration and fisher competition in the former and tourism development in the latter has led to reduced social cohesion. Such concerns re-emerged in discussions of the sea cucumber fishery and the associated spike in "outsiders", as participants brought up concerns about how their presence is or may yet impact levels of trust, friendliness and shared values in the community.

Río Lagartos, in the sense that it is now no longer quiet, already you cannot walk at night... because people are coming from other places. There are many people from Veracruz, Chiapas, many foreign people are coming and we do not know their way of life, if they are calm people. While there is tranquility there is no problem. I imagine that (the community) is going to change in many aspects, they are building some hotels on the waterfront, like how it is in Cancun, and we don't know what is going to happen. (Rancher)

We recognize here and above a strong sense of xenophobia, which may emerge from the feelings of unease resulting from rapid social change. The particulars in this case pointed to the rapid amplification and sheer volume of influx, rather than a lack of pre-existing openness or possibilities for integration of newcomers into community social structures and functioning. For example, in years prior, fishers from other communities had come to fish local species and were considered acceptable because they were smaller in number, their stay was shorter, and most were known to or related to local families. In contrast, sea cucumber fishing has resulted in a much greater number of participants, with most incoming fishers characterized as unconnected to the community and therefore without incentive to fish sustainably. While social conflicts had previously occurred in the community, as in any, the spike in intensity and frequency of violent conflict was referred to as a disturbing shift in norms. A general sense that the sea cucumber fishery marks a dramatic change in 'life-as-we-know-it' is captured below: You'd never heard of brawls and shootings at sea or something like this situation with the cucumber. The cucumber, I believe it was more like a drug, like cocaine... the cucumber is more valuable than cocaine. That there are pirates in the sea, they are going to take the fish that you have, they rob you and they take it, they fire shots, they burn boats. It has become something. (Restaurant Owner)

\subsubsection{Change in social system feedbacks}

As the sea cucumber fishery drives changes in community structure and function, interviewees mentioned several actions or responses taken by locals, at both individual and group scales. These included an increase in fishing effort, vigilance by cooperative members, organized protest, as well as simply coping with the effects and hoping for improvement.

As mentioned previously, fishers have been responding to declining fish stocks through fishing longer hours further from shore. While increasing fishing effort can function as a coping mechanism in the short term, it is often characterized as 'maladaptive' behaviour in the long term because of the increased likelihood of pushing stocks to a point of collapse (Boonstra and Hanh, 2015). For sea cucumber harvesters, this response represents an increase in both 
ecological and physiological risk. With overexploitation of nearby sea cucumber populations, divers are venturing farther from shore to harvest at increasing depths. As seasonal openings are short, and competition is growing, divers are inclined to work longer hours for more consecutive days than are safe and increase their likelihood of decompression illness or death.

For the cucumber they come to us to give courses and all but the people, let's call it greed, that if I've got 200 kilos of cucumber and it's early, I'm going to go back and get another 100 kilos because that's a little more money, but that trip sometimes causes decompression. Now several have died here from decompression. (Fisher)

With ineffective fisheries governance at the state level, the local fishing cooperatives have attempted to take on elements of regulation, monitoring, and enforcement in what can only be described as vigilante justice in method. As local fishers take action against encroaching poachers, through physical confrontations and boat burning, the continued conflict contributes to furthering the sense of insecurity.

About a year ago we went out to take care of pepineros (illegal sea cucumber harvesters), along with those (fishers) of San Felipe, together we burned their boats. (Fisher)

Though the efforts of cooperatives stemmed the influx of poachers initially, poachers soon returned better armed and in larger groups.

They began to come (back) armed, and grabbed one (fisher from) San Felipe and burned their boats too... almost killed them, it got hard. (Fisher)

Another response to the presence of illegal fishers has been protest. Cooperative fishermen of Río Lagartos have on multiple occasions created blockades at the town entrance, demanding action from state authorities. One such blockade occurred during the time of field research. For a full day, fishing activity was halted so that cooperative fishers could blockade the highway into town. Locals hoped that it would prompt state authorities to take action on poaching. Though government representatives did not show up during the protest, the blockade resulted in challenges for tourism and hospitality groups, who had busloads of disgruntled tourists waiting to get in or out of the town.

Well the most difficult (issue), where I see that there are lots of problems is that sea cucumber. I believe you already know that they (protesting fishermen) closed the highway... If you arrive and you are with your family, and you have a reservation in Cancun and you can't leave with your car, imagine it. This is what I have experienced that is really bad, it never happened here (before). (Tour Guide)

After relatively ineffective attempts to bring poachers to justice, and the physical risk that comes with efforts to monitor and defend local fishing grounds, some fishermen expressed a sense that the only option was to allow the poaching and cope with the effects until sea cucumber stocks were completely overfished. 
It is something that cannot be solved because it's like you're messing with the mafia. They are armed, there is a risk that they will hit you with a bullet. (Fisher).

For many respondents, the perception that government corruption, apathy and lack of action create a favourable environment for illegal fishing makes this challenge seem all the more daunting.

\section{Discussion}

The recent emergence of commercial sea cucumber fishing on the Yucatán Peninsula has driven fast and dramatic changes in the community of Río Lagartos. It has triggered a gold-rush style influx of new actors, new livelihood opportunities (and risks) with accompanying shifts in harvesting pressure and institutional power dynamics. In this discussion, we explore a few of the key insights of this research in greater depth, focusing on the differing impact pathways of shocks versus trends and the implications of such differences for community adaptive capacity and adaptation as well as for conceptions of feed- backs and thresholds in social systems.

\subsection{Impact pathways of shock versus trends}

Tracking the drivers and impacts of the top-mentioned social-ecological changes enables a comparison of the impact pathways of the sea cucumber fishery and the impact pathways of slower trends. From this, four key distinctions emerge. First, while social-ecological changes that were observed to be taking place over ten or more years were linked to drivers such as the establishment of the biosphere reserve, regional development, population growth, and gradual fishery declines, the majority of recent and rapid local changes were connected to the start of commercial sea cucumber fishing.

A second distinction is evident in participant perceptions of the impacts on community functioning. Slower drivers (trends) were associated with both positively and negatively perceived impacts on community functioning. In contrast, fast changes attributed to the sea cucumber fishery were consistently described as having only negative impacts on community functioning. The host of new issues and challenges that have emerged with sea cucumber fishing resulted in several respondents referring to sea cucumber as the key problem that the community faced, representing a situation where the social and ecological costs to the community outweighed the potential profits for participating fishers.

Third, changes driven by the fishery have exacerbated the negative impacts of several ongoing trends, such as gradual declines in commercially important fish stocks. As migrant fishers harvest local species other than sea cucumber, the development of the fishery has amplified the harvesting pressure on species such as lobster and grouper that have been declining since the early 2000's (Pedroza and Salas, 2011). Thus, the topic of the new sea cucumber fishery often came to the fore in conversations about local fishing livelihoods that have been challenged by declining fisheries and harvests for some time. 
Finally and as compared to trends, a large portion of the local changes mentioned were connected to the sea cucumber fishery. The substantial attention that respondents gave to impacts of the rapid- onset fishery suggests that fast and dramatic change tends to be more noticeable, disturbing and, indeed 'shocking' than slower change - a finding that also aligns with the literature on social impacts (Vanclay, 2002).

\subsection{Implications of shocks for adaptive capacity and adaptation}

Our results also speak to how adaptation and adaptive capacity might be impacted by shocks versus trends. To the extent that they are novel and unforeseen, shocks afford limited opportunities for proactive adaptation. Put another way, the more acute the change at onset, the less time local institutions have to develop response options that effectively mitigate impacts (Berkes et al., 2006; Eriksson et al., 2015). In this case study, increased illegal fishing activity triggered by the fishery boom has overwhelmed the capacity of local cooperatives to respond effectively. Such observations align with work by Carpenter et al. (2012) where they posit, "extreme events that are unusually intense or extensive require a more all-purpose kind of resilience" (p.3250). They suggest that dramatic change both "erodes capacity to organize and respond, and induces new feedbacks that tend to keep the system in the disturbed state" (Carpenter et al., 2012 p.3250), thus presenting a formidable challenge for institutions. Ultimately, greater latent adaptive capacity may be required to facilitate effective responses to shocks as compared to trends.

It should be noted that while there were a few references to youth leaving the community to seek employment, interview respondents did not specifically mention emigration of local fishers or fishing families as a response to fishing declines. So while the community has been experiencing trends (e.g. fish declines) that have incentivized emigration in other contexts (see Black et al., 2011; Ommer, 2007), a strong attachment to place and to fishing as a livelihood appears to inhibit emigration for many families in Río Lagartos.

\subsection{Shocks \& social thresholds}

In SES scholarship, shocks (or perturbations) have been of particular concern because of their potential to push a system over a critical threshold into a less desirable state (Folke et al., 2010). Much of the thresholds research in SES has focused on conceptualizing and locating thresholds in ecological systems where "crossing over" can result in significant changes in ecosystem structure, function, and feedbacks (Walker et al., 2004). A smaller but growing body of work has investigated social and institutional thresholds (Armitage et al., 2012; Nayak et al., 2015; Blythe, 2014; Christensen and Krogman, 2012). These authors conceptualize thresholds as points of change in social- ecological system identity (Blythe, 2014; Cumming et al., 2005) or points at which there is a loss of capacity to learn and adapt (Renaud et al., 2010). Yet, current threshold characterizations are limited in their ability to conceptualize and communicate thresholds in terms of the social impacts of change. For example, a threshold in socialecological system identity that is defined by points of change in a resource or livelihood may tell us little about the array of positive or negative social impacts of such changes. 
The social system framework presented in this paper may assist in identifying various social thresholds. For example, results from our case study highlight how rapid changes in components (e.g., new actors) can overwhelm the capacity of institutions (e.g. cooperatives) to maintain desired social functions. Thus, a function threshold might be understood as the point(s) at which pressure from a change is great enough to result in a loss of desired community functions, such as the ability to access or manage local resources, or a sense of social cohesion. A second conception of thresholds might focus on feedbacks. In the ecological resilience literature, system thresholds are often considered to be the point where new feedbacks begin to reinforce the direction of change toward an alternate (undesirable) domain of attraction, or system state (Davidson, 2010). In social systems, a feedback threshold might be defined as a point at which actors or institutions begin responding to change in ways that are predominantly 'maladaptive'- i.e. result in increased vulnerability in the long run. Finally, we also stress that there is a distinct difference between social thresholds and social-ecological thresholds - where the former refers to changes within the social system itself and the latter refers to a fundamental change in the nature of the relationship between social and ecological components of the system (e.g., as represented by level of impacts, types of activities, benefits from harvesting, or values towards nature). Thresholds research is clearly an area of SES scholarship requiring further development and empirical study.

\section{Conclusion}

The research presented here illustrates how rapid-onset sea cucumber fisheries, triggered by rising international demand, can emerge as 'shocks' in local social-ecological systems, driving fast and unforeseen forms of change. Interview results demonstrate how the new fishery has driven dramatic changes in the community by sparking an influx of new actors, new livelihood risks and opportunities, and creating new pressures on local environmental resources. Such dramatic changes in structural components of the social system (the community) have combined with ongoing stressors to negatively impact aspects of community functioning, including the ability to manage local marine resources, sustainability of fishing livelihoods, social cohesion, and sense of security.

By investigating a social driver of rapid change in coastal SES, this research contributes to broadening scholarship on community vulnerability and adaptation to include social stressors, while also high- lighting the need to better differentiate the impacts of stressors at varying timescales (i.e. shocks and trends). Our social systems frame- work may support future efforts to identify the community level impacts of different trends and shocks. Yet our understanding of the implications of and how to actually respond to these types of rapid changes remains limited. We highlight the need for further empirical research that: differentiates the impacts of shocks versus trends; examines how to plan for and adapt in the face of social shocks; and develops our understanding of social thresholds.

This is not just an academic exercise. As novel forms of environ- mental and social change occur at unprecedented rates, both social and biophysical shocks will continue to have significant real world con- sequences. In this context, efforts to support thriving coastal communities and the 
ecosystems upon which they depend will require a better understanding of how communities experience and respond to fast and slow changes.

\section{Acknowledgements}

This research was supported in part by funding from grants from MITACS and the Social Sciences and Humanities Research Council of Canada (SSHRC IDG Grant \#430-2014-00569; SSHRC CGSM Grant \#83434143; SSHRC Insight Grant \#435-2013-2017). NJB also acknowledges the support of the Liber Ero and Banting Postdoctoral Fellowship Programs, the Community Conservation Research Network and the OceanCanada Partnership.

\section{References}

Adger, W.N., Eakin, H., Winkels, A., 2009. Nested and teleconnected vulnerabilities to environmental change. Front. Ecol. Environ. 7 (3), 150-157. http://dx.doi.org/10.1890/070148.

Adger, W.N., Barnett, J., Brown, K., Marshall, N., O'Brien, K., 2012. Cultural dimensions of climate change impacts and adaptation. Nat. Clim. Change 3 (2), 112-117. http://dx.doi.org/10.1038/nclimate1666.

Adger, W.N., 2006. Vulnerability. Glob. Environ. Change 16 (3), 268-281. http://dx.doi.org/10.1016/j.gloenvcha.2006.02.006.

Anderson, S.C., Flemming, J.M., Watson, R., Lotze, H.K., 2010. Serial exploitation of global sea cucumber fisheries. Fish Fish. 12 (3), 317-339. http://dx.doi.org/10.1111/j.1467-

2979.2010.00397.x.

Armitage, D.R., Johnson, D., 2006. Can resilience be reconciled with globalization and the increasingly complex conditions of resource degradation in Asian coastal regions? Ecol. Soc. 11 (1), 2. http://www.ecologyandsociety.org/vol11/iss1/art2/.

Armitage, D., Béné, C., Charles, A.T., Johnson, D., Allison, E.H., 2012. The interplay of well-being and resilience in applying a social-ecological perspective. Ecol. Soc. 17 (4).

http://dx.doi.org/10.5751/ES-04940-170415.

Bardsley, D.K., Wiseman, N., 2013. Climate change vulnerability and social development for remote indigenous communities of South Australia. Glob. Environ.

Bennett, N., Dearden, P., Peredo, A.M., 2015. Vulnerability to multiple stressors in coastal communities: a study of the Andaman Coast of Thailand. Clim. Dev. 7, 124-141.

Bennett, N.J., Blythe, J., Tyler, S., Ban, N.C., 2016. Communities and change in the anthropocene: understanding social-ecological vulnerability and planning adaptations to multiple interacting exposures. Reg. Environ. Change 1-20. http://dx.doi.org/10.1007/s10113015-0839-5. 
Bennett, A., 2016a. Small-scale Fisheries and the Global Economy: Understanding Commonpool Resource Governance in the Context of Market Pressures, Neoliberal Policies, and Transnational Institutions. Duke University (Doctoral Dissertation).

Bennett, N.J., 2016b. Using perceptions as evidence to improve conservation and environmental management. Conserv. Biol. 3, 582-592. http://dx.doi.org/10.1111/cobi.12681.

Berkes, F., Hughes, T.P., Steneck, R.S., Wilson, J.A., Bellwood, D.R., Crona, B., Folke, C., Gunderson, L.H., Leslie, H.M., Norberg, J., Nyström, M., Olsson, P.H., Österblom, H., Scheffer, M., Worm, B., 2006. ECOLOGY: globalization, roving bandits, and marine resources. Science 311 (5767), 1557-1558. http://dx.doi.org/10.1126/science.1122804.

Birk, T., 2014. Assessing vulnerability to climate change and socioeconomic stressors in the Reef Islands group, Solomon Islands. Geografisk Tidsskrift-Dan. J. Geogr. 114 (1), 59-75. http://dx.doi.org/10.1080/00167223.2013.878228.

Black, R., Adger, W.N., Arnell, N.W., Dercon, S., Geddes, A., Thomas, D.S.G., 2011. The effect of environmental change on human migration. Glob. Environ. Change 21, S3-S11. http://dx.doi.org/10.1016/j.gloenvcha.2011.10.001.

Blythe, J.L., 2014. Resilience and social thresholds in small-scale fishing communities. Sustain. Sci. 10 (1), 157-165. http://dx.doi.org/10.1007/s11625-014-0253-9.

Boonstra, W.J., Hanh, Tong Thi Hai, 2015. Adaptation to climate change as social-ecological trap - a case study of fishing and aquaculture in the Tam Giang Lagoon, Vietnam. Environ. Dev. Sustain. 17 (6), 1527-1544.

Bremner, Jason, Perez, Jaime, 2002. A case study of human migration and the sea cucumber crisis in the galapagos islands. Ambio 31 (4), 306-310. (Published by: Springer on behalf of Royal Swedish Academy of Sciences). http://www.jstor.org/stable/4315257.

Breslow, S.J., 2015. Accounting for neoliberalism: social drivers in environmental management. Mar. Policy 61 (C), 420-429. http://dx.doi.org/10.1016/j.marpol.2014.11.018.

Bromet, E.J., Havenaar, J.M., Guey, L.T., 2011. A 25 year retrospective review of the psychological consequences of the Chernobyl accident. Clin. Oncol. 23 (4), 297-305. http://www.sciencedirect.com/science/article/pii/S0936655511005334.

Bunce, M., Brown, K., Rosendo, S., 2010. Policy misfits, climate change and cross-scale vulnerability in coastal Africa: how development projects undermine resilience. Environ. Sci. Policy 13 (6), 485-497. http://dx.doi.org/10.1016/j.envsci.2010.06. 003. 
Carpenter, S., Arrow, K., Barrett, S., Biggs, R., Brock, W., Crépin, A.-S., et al., 2012. General resilience to cope with extreme events. Sustainability 4 (12), 3248-3259.

http://dx.doi.org/10.3390/su4123248.

Christensen, L., Krogman, N., 2012. Social thresholds and their translation into social- ecological management practices. Ecol. Soc. 17 (1), 5-9. http://dx.doi.org/10.5751/ES-04499-170105.

Christensen, A.E., 2011. Marine gold and atoll livelihoods: the rise and fall of the bêche-de-mer trade on Ontong Java, Solomon Islands. Nat. Resour. Forum 35, 9-20.

Cinner, J.E., Pratchett, M.S., Graham, N.A.J., Messmer, V., Fuentes, M.M.P.B., Ainsworth, T., et al., 2015. A framework for understanding climate change impacts on coral reef social-ecological systems. Reg. Environ. Change 1-14. http://dx.doi.org/10.1007/s10113-015-0832-z.

Cote, M., Nightingale, A.J., 2012. Resilience thinking meets social theory: situating social change in socio-ecological systems (SES) research. Prog. Hum. Geogr. 36 (4), 475-489.

http://dx.doi.org/10.1177/0309132511425708.

Davidson, D., 2010. The applicability of the concept of resilience to social systems: some sources of optimism and nagging doubts. Soc. Nat. Resour. 23 (12), 1135-1149. http://dx.doi.org/10.1080/08941921003652940.

Engle, N.L., 2011. Adaptive capacity and its assessment. Glob. Environ. Change 21 (2), 647-656. http://dx.doi.org/10.1016/j.gloenvcha.2011.01.019.

Eriksson, H., Österblom, H., Crona, Beatrice, Troell, Max, Andrew, Neil, Wilen, James, Folke, Carl, 2015. Contagious exploitation of marine resources. Front. Ecol. Environ. 13 (8), 435-440. http://dx.doi.org/10.1890/140312.

Folke, C., Carpenter, S.R., Walker, B., Scheffer, M., Chapin, T., Rockström, J., 2010. Resilience thinking: integrating resilience, adaptability and transformability. Ecol. Soc. 15 (4), 20. ([online] URL:). http://www.ecologyandsociety.org/vol15/iss4/art20/.

Folke, C., 2006. Resilience: the emergence of a perspective for social-ecological systems analyses. Glob. Environ. Change 16 (3), 253-267. http://dx.doi.org/10.1016/j.gloenvcha.2006.04.002.

Fraga, J., 2006. Local perspectives in conservation politics: the case of the Ría Lagartos Biosphere Reserve, Yucatán, México. Landsc. Urban Plan. 74 (3-4), 285-295.

http://dx.doi.org/10.1016/j.landurbplan.2004.09.008.

Freudenburg, W., Gramling, R., Laska, S., Erikson, K.T., 2008. Organizing hazards, engineering disasters? Soc. Forces 87 (2), 1015-1038. 
Gallopín, G.C., 2006. Linkages between vulnerability, resilience, and adaptive capacity.

Glob. Environ. Change 16 (3), 293-303. http://dx.doi.org/10.1016/j.gloenvcha.2006.02.004.

Grothmann, T., Patt, A., 2005. Adaptive capacity and human cognition: the process of individual adaptation to climate change. Glob. Environ. Change 15 (3), 199-213.

http://dx.doi.org/10.1016/j.gloenvcha.2005.01.002.

Hicks, C.C., Crowder, L.B., Graham, N.A., Kittinger, J.N., Cornu, E.L., 2016. Social drivers forewarn of marine regime shifts. Front. Ecol. Environ. 14 (5), 252-260.

http://dx.doi.org/10.1002/fee.1284.

Holling, C.S., 1973. Resilience and stability of ecological systems. Annu. Rev. Ecol. Syst. 4, 1-23.

Hugo Michel, V., 2013. Yucatán Vive 'fiebre De Oro' Con Su Pepino De Mar Millenio Novedades Online. (Available at:). http://sipse.com/milenio/el-porque-de-la-fiebre-del-pepino-de-marvideo-16648.html.

Julca, A., Paddison, O., 2010. Vulnerabilities and migration in Small Island Developing States in the context of climate change. Nat. Hazards 55, 717-728.

Leichenko, R., O'Brien, K., 2008. Environmental Change and Globalization: Double Exposures. Oxford University Press, Oxford.

Lorenz, D.F., 2010. The diversity of resilience: contributions from a social science perspective. Nat. Hazards 67 (1), 7-24. http://dx.doi.org/10.1007/s11069-010-9654-y.

Lyons, C., Carothers, C., Reedy, K., 2016. Means, meanings, and contexts: a framework for integrating detailed ethnographic data into assessments of fishing community vulnerability. Mar. Policy 1-10. http://dx.doi.org/10.1016/j.marpol.2016.04.022.

McCubbin, S., Smit, B., Pearce, T., 2015. Where does climate fit? Vulnerability to climate change in the context of multiple stressors in Funafuti, Tuvalu. Glob. Environ. Change 30, 43-55. http://dx.doi.org/10.1016/j.gloenvcha.2014.10.007.

Mee, L., 2012. Between the Devil and the Deep Blue Sea: the coastal zone in an Era of globalisation. Estuarine Coast. Shelf Sci. 96, 1-8. http://dx.doi.org/10.1016/j.ecss.2010.02.013.

Merriam, S.B., 2001. Qualitative Research and Case Study Applications in Education, 2nd edition. Jossey-Bass, San Francisco, pp. 22-35 (Chapter 2).

Miller, W., Crabtree, B., 2004. Depth Interviewing. In Approaches to Qualitative Research. In: Denzin, Lincoln (Eds.), new 2nd edition. Sage, Thousand Oaks, CA, pp. 509-535. 
Nayak, P.K., Armitage, D., Andrachuk, M., 2015. Power and politics of social-ecological regime shifts in the Chilika lagoon, India and Tam Giang lagoon, Vietnam. Reg.

Environ. Change 1-15. http://dx.doi.org/10.1007/s10113-015-0775-4.

O'Brien, K., Leichenko, R., Kelkar, U., Venema, H., Aandahl, G., Tompkins, H., et al., 2004.

Mapping vulnerability to multiple stressors: climate change and globalization in India. Glob.

Environ. Change 14 (4), 303-313. http://dx.doi.org/10.1016/j.gloenvcha.2004.01.001.

Ommer, R., 2007. Coasts Under Stress: Restructuring and Social-ecological Health.

McGill-Queen's University Press ISBN: 0-7735-3203-X, 978-0-7735-3203-8.

Ostrom, E., 2009. A general framework for analyzing sustainability of social-Ecological systems. Science 325 (5939), 419-422. http://dx.doi.org/10.1126/science.1172133.

Pauly, D., Maclean, J.L., 2003. In a Perfect Ocean: The State of Fisheries and Ecosystems in the North Atlantic Ocean. Island Press, Washington.

Pedroza, C., Salas, S., 2011. Responses of the fishing sector to transitional constraints From reactive to proactive change, Yucatán fisheries in Mexico. Mar. Policy 35 (1), 39-49.

http://dx.doi.org/10.1016/j.marpol.2010.08.001.

Prno, J., Bradshaw, B., Wandel, J., Pearce, T., Smit, B., Tozer, L., 2011. Community vulnerability to climate change in the context of other exposure-sensitivities in Kugluktuk, Nunavut. Polar Res. 30, 1-21.

Reid, P., Vogel, C., 2006. Living and responding to multiple stressors in South Africa-glimpses from KwaZulu-Natal. Glob.I Environ. Change 16 (2), 195-206.

http://dx.doi.org/10.1016/j.gloenvcha.2006.01.003.

Renaud, F.G., Birkmann, J., Damm, M., Gallopín, G.C., 2010. Understanding multiple thresholds of coupled socia-ecological systems exposed to natural hazards as external shocks. Nat. Hazards 55 (3), 749-763. http://dx.doi.org/10.1007/s11069-010-9505-x.

Schwarz, A.M., Béné, C., Bennett, G., Boso, D., Hilly, Z., Paul, C., et al., 2011. Vulnerability and resilience of remote rural communities to shocks and global changes: empirical analysis from Solomon Islands. Glob. Environ. Change 21 (3), 1128-1140.

http://dx.doi.org/10.1016/j.gloenvcha.2011.04.011.

Smit, B., Wandel, J., 2006. Adaptation, adaptive capacity and vulnerability. Glob.

Environ. Change 16 (3), 282-292. http://dx.doi.org/10.1016/j.gloenvcha.2006.03.008.

Tobin, G., Montz, B., 1997. Natural Hazards: Explanation and Integration. Guildford Press (ISBN 9781572300620). 
Tschakert, P., 2007. Views from the vulnerable: understanding climatic and other stressors in the Sahel. Glob. Environ. Change 17 (3-4), 381-396.

http://dx.doi.org/10.1016/j.gloenvcha.2006.11.008.

Turner, B.L., Kasperson, Roger E., Matson, Pamela A., McCarthy, James J., Corell, Robert W., Christensen, Lindsey, Eckley, Noelle, Kasperson, Jeanne X., Luers, Amy, Martello, Marybeth L., Polsky, Colin, Pulsipher, Alexander, Schiller, Andrew, 2003. A framework for vulnerability analysis insustainability science. PNAS 100, 14.

UNESCO, Man in biosphere reserves directory, Available at:

http://www.unesco.org/mabdb/br/brdir/directory/biores.asp?mode=all\&code=MEX+16.

Vanclay, F., 2002. Conceptualising social impacts. Environ. Impact Assess. Rev. 22, 183-211.

Walker, B.H., Holling, C.S., Carpenter, S.R., Kinzig, A., 2004. Resilience, adaptability and transformability in social-ecological systems. Ecol. Soc. 9 (2), 5.

http://www.ecologyandsociety.org/vol9/iss2/art5.

Walker, B.H., Carpenter, S.R., Rockstrom, J., Crépin, A.-S., Peterson, G.D., 2012. Drivers, slow variables, fast variables, shocks, and resilience. Ecol. Soc. 17 (3). http://dx.doi.org/10.5751/ES05063-170330.

Wise, R.M., Fazey, I., Stafford Smith, M., et al., 2014. Reconceptualising adaptation to climate change as part of pathways of change and response. Glob. Environ. Change 28, 325-336. http://dx.doi.org/10.1016/j.gloenvcha.2013.12.002. 